\title{
Selected Abbreviations and Acronyms
}

\author{
ANT Actor-Network Theory \\ APPA Asylpraxis/Pratique en matière d'asile: Internal document \\ outlining the asylum practice for a country of origin \\ AsylA Swiss Asylum Act \\ CBCA Criteria-Based Content Analysis \\ COI Country of Origin Information \\ DAWES Dismissal of Admission Without Entering into the Substance \\ of the case (Nichteintretensentscheid NEE) \\ EMARK Entscheidungen und Mitteilungen derARK (Rulings and \\ notifications of the AAC) \\ EURODAC EU asylum fingerprint database \\ FAC Federal Administrative Court (Bundesverwaltungsgericht \\ BVGer) \\ FNA Swiss Foreign Nationals Act \\ FOM Federal Office for Migration (Bundesamt für Migration BFM). \\ (FOM became the State Secretariat for Migration SEM in 2015.) \\ IOM International Organisation for Migration \\ LINGUA Specialized unit for analyses of origin in Switzerland \\ NPM New Public Management \\ SAM Specialized unit for hearing management in the headquarters \\ of the SEM \\ SEM State Secretariat for Migration (Staatssekretariat für Migration) \\ STS Science, Technology and Society or Science and Technology \\ Studies \\ UNHCR United Nations High Commissioner for Refugees \\ ZEMIS Zentrales Migrationsinformationssystem (Central migration \\ information system)
}


